\title{
OBSERVATIONS ON THE EFFECT OF ORGANIC MATERIAL UPON AGGREGATION AND NITRATE-NITROGEN CONTENT OF SOIL.
}

\author{
By \\ Armi Kaila and Pertti Kivinen \\ University of Helsinki, Department of Agricultural Chemistry.
}

Received 1st September 1952.

An application of energy-yielding material into soil, poor in organic matter, usually gives rise to a marked increase in the activity of microflora, provided environmental conditions are favourable for the development of microbial population. As a result of this activity the evolution of carbon dioxide from the soil intensifies, further an immobilization of mineral nitrogen and of other nutrients may take place, and also an aggregation of soil particles can be found to occur during the decomposition of the organic material added. Generally, the immobilization of nutrients must be considered undesirable, the aggregation of soil again an advantageous process. In order to throw some light upon the relationship of these phenomena, a series of laboratory experiments were performed where the nitrate-nitrogen content of the soil and the amount of water-stable aggregates in it were taken to indicate the intensity of the immobilization of nitrogen and the crumb formation caused by additions of various organic materials.

Methods

All the experiments were run only in the laboratory scale. Ground, air-dry soil was weighed in pots, and the organic material, ground in a Wiley mill, was mixed as dry into the soil. The moisture of the soil was arranged to correspond to the field capacity, and the pots were incubated for various times.

After the incubation the soil samples were air-dried and analyzed for water-soluble aggregates larger than $0.5 \mathrm{~mm}$ in diameter by the method of SwABY (7), and for nitrate-nitrogen by the somewhat modified phenol-disulphonic acid method of BERGE (1). 


\section{Evperiments.}

In the first experiment the influence of various organic material upon the nitratenitrogen content and upon the aggregation of two soils was studied. The soils were a slightly acid finesand clay, $\mathrm{pH} 6.2$, and a strongly acid muddy clay, $\mathrm{pH} 4.3$. These soils were incubated with glucose, fresh and fermented wheat straw, fresh and fermented farm manure, fresh green fodder (mixture of oats and pea in flower), roots and stubble of red clover, and with two peat samples, one Sphagnum peat moss and the other a sample of lowmoor peat. An amount corresponding to $1 \%$ of the weight of the soil was added. The incubation took place at $25^{\circ} \mathrm{C}$. Samples were taken after periods of 45 and of 120 days. The results of analyses are in Table 1.

Table 1. Nitrate-nitrogen and water-stable aggregates larger than $0.5 \mathrm{~mm}$ in diameter in finesand clay and muddy clay samples incubated with an addition of various organic materials for 45 and 120 days.

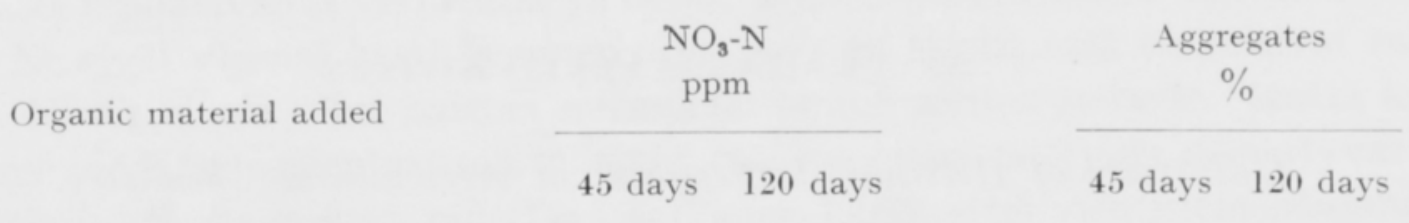

I. Finesand clay, $\mathrm{pH} 6.2$

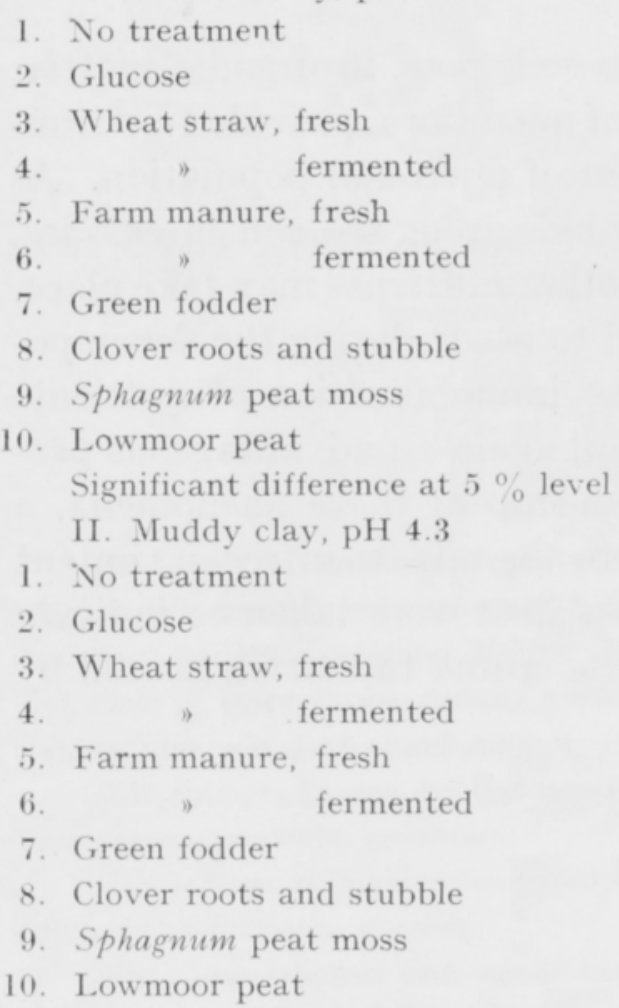

Significant difference at $5 \%$ level

$\begin{array}{rrrr}122 & 245 & 14 & 60 \\ 51 & 155 & 33 & 63 \\ 36 & 153 & 32 & 77 \\ 82 & 178 & 22 & 46 \\ 89 & 200 & 23 & 51 \\ 118 & 215 & 15 & 58 \\ 96 & 218 & 22 & 54 \\ 185 & 268 & 34 & 54 \\ 113 & 268 & 14 & 53 \\ 133 & 283 & 13 & 54 \\ & & 7 & 10\end{array}$

$\begin{array}{rlll}8 & 15 & 62 & 82 \\ 6 & 27 & 80 & 93 \\ 5 & 35 & 68 & 93 \\ 6 & 15 & 62 & 84 \\ 9 & 33 & 67 & 87 \\ 11 & 29 & 64 & 78 \\ 6 & 36 & 69 & 88 \\ 12 & 53 & 74 & 86 \\ 13 & 32 & 63 & 78 \\ 13 & 45 & 62 & 71\end{array}$

The nitrate-nitrogen content of the original finesand clay sample was $14 \mathrm{ppm}$, and that of the muddy clay $5 \mathrm{ppm}$. The incubation for 45 days has increased this 
amount nearly ten times in the finesand clay, but only slightly in the acid clay. Glucose, fresh and fermented wheat straw, fresh farm manure and green fodder have caused a depression in the formation of nitrate-nitrogen in both soils, although this phenomenon is much less marked in the acid soil sample than in the other one. No retardation of nitrification can be found in the muddy clay samples incubated with various materials for 120 days, on the contrary, the data reveal a fairly marked increase in the nitrate-nitrogen content of the treated samples as compared to that of the untreated one. In the finesand clay samples the mobilization of indigenous nitrogen during the incubation for 120 days has exceeded the formation of nitrate in the samples from the treatments $2-7$.

After an incubation of 45 days the aggregation in the finesand clay samples treated with glucose, fresh wheat straw and with clover roots and stubble was more than twofold of that of the untreated one, and also fresh farm manure, fermented wheat straw, and green fodder were able to cause a higher aggregation percentage as compared to that of the untreated sample. Similar results, though less marked, were obtained also from the muddy clay samples after the first incubation period. The second sampling, however, indicates that the aggregating effect upon the finesand clay of all other materials except fresh wheat straw lasted less than for three months. In the acid clay, on the contrary, the cementing material, formed during the decomposition of glucose, fresh straw, farm manure and green fodder was more durable, or probably the microbial activity less intensive than in the slightly acid clay.

Thus these results indicate that the effect of organic matter upon soil properties largely depends on the conditions the soil possesses for the development of microbial flora. In a fertile soil the immobilization of nitrogen may be relatively higher than in an unfertile one, and in the former the crumb formation and destruction takes place more intensively and more rapidly than in the latter one. Yet, the undesirable effect of the immobilization of nitrogen may be more dangerous in the less fertile soil, since it is much poorer in mineral nitrogen and mobilizable nitrogen than the richer one.

Peat samples and fermented farm manure did not have any effect upon the aggregation state or upon the nitrate-nitrogen content of the soils in this experiment. They are known to be poor in readily available energy-yielding compounds which in the other materials obviously gave rise to a vigorous development of microbial population. Although the crumb formation does not exclusively depend on the activity of microorganisms, they play an important role in the processes, due to their metabolic products and to the binding effect of their cells and mycelia. And in the destruction of the crumbs the microflora acts as decomposers of the cementing compounds. Fresh straw and fresh farm manure showed a more pronounced effect upon immobilization of nitrogen and upon the crumb formation than did the fermented samples, a fact obviously connected with the content of readily available carbon compounds in these materials. To study this point more thoroughly an experiment was arranged where samples of finesand clay, $\mathrm{pH} 5.6$, were incubated with additions of straw compost that represented various degrees of decomposition. The appli- 
Table 2. Influence of the degree of decomposition upon the effect of straw compost on soil.

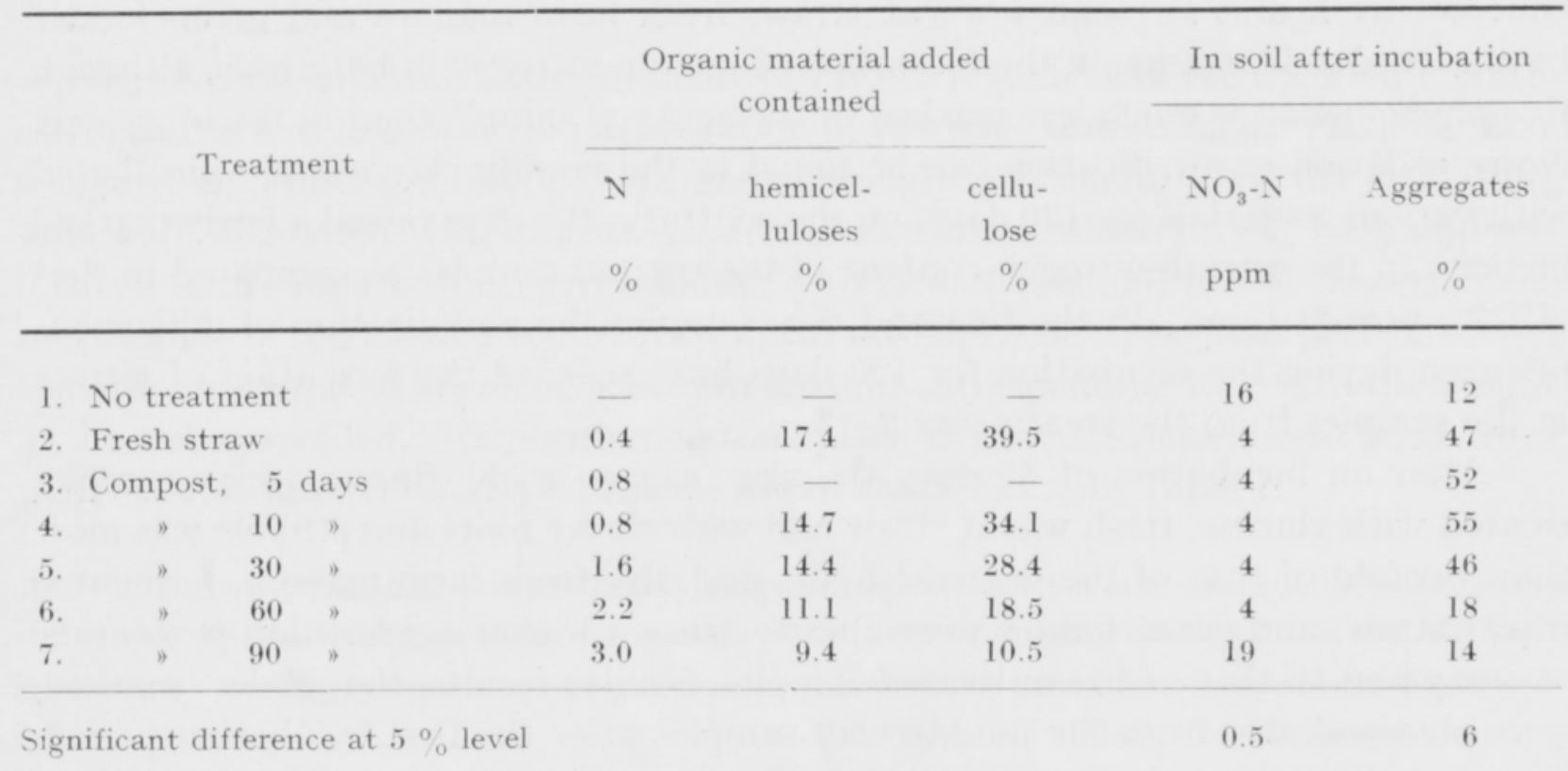

cation of compost corresponded to $2 \%$ of the weight of soil, and the period of incubation was two months. The results are reported in Table 2. It also presents data for the nitrogen, hemicellulose and cellulose content of the material added, the last two figures obtained by the fractionation method of Waksman.

After an incubation of two months at $20^{\circ} \mathrm{C}$ the samples of organic material containing hemicelluloses more than $9.4 \%$ and cellulose more than $10.5 \%$ of dry matter had caused immobilization of nitrogen. The aggregating effect of organic material was obtainable only in the samples the hemicellulose content of which was higher than $11.1 \%$ and the cellulose content higher than $18.5 \%$. Thus the crumb formation appears to need more energy-yielding material than the immobilization of nitrogen, or the destruction of crumbs occur more rapidly than the mineralization of biologically bound nitrogen. This relationship was found also in some previous experiments (4) .

Since it seemed probable that the amount of organic material added as well as the nutritional conditions in the soil may have an effect upon the activity of microbial population, these points were studied in experiments where various amounts of straw and of nitrogen and phosphorus fertilizers were incubated with soil samples. In the first experiment the silt samples were incubated for 20 and 60 days at $18^{\circ} \mathrm{C}$, in the second experiment the soil was finesand clay and the incubation period 240 days. The amounts of mature rye straw added were 1 and $2 \%$ and the quantity of nitrogen, $1 \mathrm{~N}$, applied as urea corresponded to $0.7 \%$ of air-dry straw, that of phosphorus, $1 \mathrm{P}$, was $0.1 \%$ of air-dry straw and it was given as potassium monophosphate. These results are reported in Tables 3 and 4 .

In both of the experiments the larger amount of straw has caused a higher degree of aggregation, if the corresponding fertilizer treatments are compared. In the immobilization of nitrogen no difference between the various applications of 
Table 3. Nitrate-nitrogen and aggregates in soil incubated with various amounts of straw, nitrogen and phosphorus fertilizers for 20 and 60 days.

\begin{tabular}{|c|c|c|c|c|c|c|c|c|}
\hline & \multicolumn{4}{|c|}{$\begin{array}{c}\text { Aggregates larger than } 0.5 \mathrm{~mm} \\
\%\end{array}$} & \multicolumn{4}{|c|}{$\begin{array}{l}\mathrm{NO}_{3}-\mathrm{N} \\
\text { ppm }\end{array}$} \\
\hline & \multicolumn{2}{|c|}{20 days } & \multicolumn{2}{|c|}{60 days } & \multicolumn{2}{|c|}{20 days } & \multicolumn{2}{|c|}{60 days } \\
\hline No treatment & \multicolumn{2}{|c|}{11} & \multicolumn{2}{|c|}{16} & \multicolumn{2}{|c|}{11} & \multicolumn{2}{|c|}{30} \\
\hline Straw & $1 \%$ & $2 \%$ & $1 \%$ & $2 \%$ & $1 \%$ & $2 \%$ & $1 \%$ & $2 \%$ \\
\hline No fertilizers & 18 & 18 & 34 & 38 & 2 & 3 & 4 & 3 \\
\hline $1 \mathrm{~N}$ & 17 & 23 & 27 & 38 & 3 & 4 & 4 & 5 \\
\hline $1 \mathrm{P}$ & 20 & 30 & 26 & 38 & 3 & 2 & 6 & 7 \\
\hline $1 \mathrm{~N} \mathrm{P}$ & 22 & 34 & 22 & 37 & 3 & 0 & 10 & 8 \\
\hline $2 \mathrm{~N} \mathrm{P}$ & 27 & 38 & 22 & 33 & 10 & 10 & 29 & 43 \\
\hline
\end{tabular}

Table 4. Nitrate-nitrogen and aggregates in soil incubated with various amounts of straw, nitrogen and phosphorus fertilizers for 240 days.

$\left.\begin{array}{cc}\text { Aggregates }>0.5 \mathrm{~mm} \\ \%\end{array}\right) \begin{gathered}\mathrm{NO}_{3}-\mathrm{N} \\ \mathrm{ppm}\end{gathered}$

No treatment

7

23

Straw $1 \% \quad$ Straw $2 \% \quad$ Straw $1 \% \quad$ Straw $2 \%$

$\begin{array}{lllll}\text { No fertilizers } & 53 & 88 & 0 & 0 \\ 1 \mathrm{~N} & - & 93 & 0 & 0 \\ 1 \mathrm{P} & 46 & 87 & 0 & 0 \\ 1 \mathrm{~N} \mathrm{P} & 43 & 87 & 0 & 0 \\ 2 \mathrm{~N} \mathrm{P} & - & 68 & 0 & 0\end{array}$

Significant difference at $5 \%$ level

4

1

straw could be found, obviously it is due to the fact that the lower amount was enough to lead to an almost quantitative absorption of nitrogen by microbes.

An examination of the data for the various treatments with fertilizers reveals a fairly distinct tendency towards a more intensive crumb formation with increasing nitrogen and phosphorus applications in the samples incubated for 20 days. After a longer incubation period 60 or 240 days, the tendency appears to be the contrary. This can be explained by the fact that a larger supply of nitrogen and phosphorus gives rise to a more numerous and more intensive microflora than the lower one. 
Table 5. Influence of lime upon aggregation and nitrate-nitrogen content of soil incubated with fresh and fermented straw.

\begin{tabular}{|c|c|c|c|c|c|c|}
\hline \multirow{3}{*}{ Treatment } & \multirow{2}{*}{\multicolumn{2}{|c|}{$\mathrm{pH}$}} & \multirow{2}{*}{\multicolumn{2}{|c|}{$\begin{array}{c}\text { Aggregates }>0.5 \mathrm{~mm} \\
\%\end{array}$}} & \multirow{2}{*}{\multicolumn{2}{|c|}{$\begin{array}{l}\mathrm{NO}_{3}-\mathrm{N} \\
\mathrm{ppm}\end{array}$}} \\
\hline & & & & & & \\
\hline & 0 & $\mathrm{CaCO}_{3}$ & 0 & $\mathrm{CaCO}_{3}$ & 0 & $\mathrm{CaCO}_{3}$ \\
\hline No treatment & 5.6 & 6.5 & 11 & 9 & 105 & 125 \\
\hline Fresh straw, $1 \%$ & 5.6 & 6.7 & 21 & 21 & 13 & 38 \\
\hline Fresh straw + NP & 5.6 & 6.7 & 16 & 16 & 39 & 38 \\
\hline Fermented straw & 5.5 & 6.9 & 13 & 13 & 15 & 15 \\
\hline Fermented straw $+\mathrm{NP}$ & 5.7 & 6.9 & 12 & 12 & 55 & 46 \\
\hline
\end{tabular}

Thus the crumb formation may proceed rapidly in the former case, but also the destruction period begins sooner. In addition to this, the various nutritional conditions of microorganisms may lead to accumulation of metabolic products of different kind. It has indeed been established that under conditions of limited nitrogen supply many bacteria produce polyuronide gums (5), known to be of importance as aggregating substances.

The silt soil used in the former experiment seems to have been richer in mobilizable nitrogen than the latter one, the finesand clay sample, since in the former the double amount of nitrogen fertilizers has been enough to maintain the level of nitrate-nitrogen equal to that in the untreated one.In spite of nitrogen applications, after an incubation of 240 days no mineral nitrogen could be found in the finesand clay sample treated with straw. These results indicate that the amount of nitrogen fertilizers necessary to prevent immobilization of soil nitrogen in connection with application of straw depends on the properties of the soil and probably also on other environmental conditions. This fact, pointed out already by JESSEN and GERDum (3) may be one cause for the disagreement of many field experiments concerning the utilization of fresh straw.

Another point of which there exist contradictory informations in the literature is the influence of lime upon the soil structure. According to recent investigations lime seems to be only of minor importance as far as the aggregation of soil particles is in question $(2,6)$. Similar results were obtained also in an experiment where soil samples were incubated with additions of fresh or fermented straw, and with or without an application of calcium carbonate. The soil was finesand clay, the time of incubation two months and the incubation temperature $18^{\circ} \mathrm{C}$. The results are presented in Table 5 .

Similar results were obtained also in some other experiments where various amounts of straw was added with and without an application of lime. And when straw composts fermented with different amounts of lime were incubated in soil for two months the results were as follows: 


$\begin{array}{lccc}\text { Straw compost with } & \mathrm{pH} & \begin{array}{c}\text { Aggregates } \\ \%\end{array} \\ 0 \mathrm{CaCO} \quad \ldots \ldots \ldots \ldots & 5.6 & 10 & \begin{array}{c}\mathrm{NO}_{3}-\mathrm{N} \\ \mathrm{ppm}\end{array} \\ 15 \% \mathrm{CaCO} \ldots \ldots \ldots & 6.5 & 10 & 127 \\ 30 \% \mathrm{CaCO} \ldots \ldots \ldots & 6.9 & 9 & 115\end{array}$

Thus the organic substances formed during decomposition in the presence of calcium carbonate did not posses any greater ability to aggregate soil particles than the compounds in a compost without lime. In this as well as in the former experiment lime could not be found to exert any effect upon the nitrification in soil where organic material had been added. Probably, the results would have been different had more acid soils been used.

\section{$D i s c u s$ sion and summary.}

In the experiments reported above the effect of organic material upon the aggregation of soil particles and the simultaneous immobilization of mineral nitrogen by microorganisms were studied. The relative amount of water-stable aggregates larger than $0.5 \mathrm{~mm}$ in diameter was considered to indicate the aggregation state of the soil samples. Probably, somewhat different results were obtained if the crumb formation had been determined by some other method, but it is not sure that these would have been more reliable. Since the incubation of soil samples were performed under aerobic conditions, and all the samples were mineral soils, it seemed justifiable to take the nitrate-nitrogen content of the soil samples to characterize the amount of mineral nitrogen in them.

On the basis of the results the general conclusion may be drawn that the more favourable the conditions are for the development of an active and large microflora in the soil, the more intensively the crumb formation and the immobilization of nitrogen takes place, but also the destruction of aggregates begins the more rapidly. This appeared to be true with regard to the indigenous fertility of soil as well as to the fertilization. Liming, however, did not improve the conditions in these experiment, probably due to the rather slight acidity of the soil samples used.

Under otherwise similar conditions the larger amount of straw produced larger amount of aggregates, but the differences in the nitrate-nitrogen content of soil in the presence of various amounts of straw were neglibigle. Generally, the degree of immobilization of soil nitrogen seemed largely to depend on the properties of soil and on other environmental conditions, and nitrogen applications, theoretically enough for the needs of microorganisms that decomposed the straw, could not always prevent an intensive absorption of soil nitrogen.

The crumb formation appeared to need more energy-yielding material than the immobilization of nitrogen, or the destruction of crumbs occurred more rapidly than the nitrification of microbiologically bound nitrogen. 


\title{
R E F E R E N C E S.
}

(1) Berge, T. O. 1941. Determination of nitrate-nitrogen with a photoelectric colorimeter. Soil Sci. $52 ;$ p. $185-191$.

(2) Browning, G. M. and Millam, F. M. 1944. Effect of different types of organic materials and lime on soil aggregation. Soil Sci. 57, p. 91-106.

(3) Jessen, W. und Gerdum, E. 1931. Zur Frage der Strohdüngung. Zeitschr. Pflanzenern., Düng. u. Bodenk. B 10, p. 97-102.

(4) KaIlA, A. 1952. Observations on the effect of nitrogen and phosphorus upon the humification of straw. Acta Agr. Fenn. 78.2.

(5) Norman, A. G. and Bartholomew, W. V. 1940. The action of some mesophilic bacteria on cellulose. Proc. Soil Sci. Soc. Amer. 5, p. 242-247.

(6) Peele, T. C. 1937. The effect of lime and organic matter on the erodibility of Cecil clay. Proc. Soil Sci. Soc. Amer. 2, p. $79-84$.

(7) Swaby, R. J. 1950. The influence of humus on soil aggregation. J. Soil Sci. 1, p. $182-194$.

S E L OS T US.

\section{HAVAINTOJA ORGAANISEN AINEKSEN VAIKUTUKSESTA MAAN MURUSTUMISEEN JA NITRAATTITYPEN PITOISUUTEEN.}

\author{
Armi Kaila ja Pertit Kivinen \\ Helsingin yliopiston maanviljelyskemian laitos.
}

Tutkimuksessa on pyritty selvittämään laboratoriossa suoritetuin muhituskokein, miten erilaisen orgaanisen aineksen lisääminen maahan vaikuttaa sen mikrobitoimintaan. Indikaattoreina on pidetty maan murustumisasteen ja nitraattitypen määrän muutoksia.

Todettiin, että mitä suotuisammat olosuhteet vallitsevat maassa, sitä nopeampaa ja tehokkaampaa ovat sekä murujen muodostuminen että typen immobilisoituminen, mutta toisaalta myös murujen hajaantuminen tapahtuu suhteellisesti nopeammin. Tämä voitiin havaita sekä silloin, kun maiden luontainen viljavuus ja etenkin happamuus olivat erilaiset, että silloin, kun lannoituksena annetut typen ja fosforin määrät olivat erilaiset. Kalkituksella ei ollut näissä kokeissa vaikutusta maan murustumiseen tai nitraattitypen määrän muutoksiin.

Murujen muodostuminen näytti vaativan enemmän helposti hajaantuvaa orgaanista ainesta kuin typen immobilisoituminen, tai murujen hajaantuminen tapahtui suhteellisesti nopeammin kuin typen mineraloituminen. Muuten samanlaisissa olosuhteissa suurempi olkimäärä johti runsaampaan murujen muodostumiseen, mutta typen immobilisoitumisen aste näytti riippuvan enemmän maan ominaisuuksista ja muista ympäristötekijöistä kuin oljen ja lisätyn mineraalitypen määrien keskinäisestä suhteesta. 